\title{
Bacteria in the global atmosphere - Part 2: Modeling of emissions and transport between different ecosystems
}

\author{
S. M. Burrows, T. Butler, P. Jöckel, H. Tost, A. Kerkweg, U. Pöschl, and M. G. Lawrence \\ Max Planck Institute for Chemistry, Mainz, Germany \\ Received: 6 March 2009 - Published in Atmos. Chem. Phys. Discuss.: 4 May 2009 \\ Revised: 6 November 2009 - Accepted: 9 November 2009 - Published: 10 December 2009
}

\begin{abstract}
Bacteria are constantly being transported through the atmosphere, which may have implications for human health, agriculture, cloud formation, and the dispersal of bacterial species. We simulate the global transport of bacteria, represented as $1 \mu \mathrm{m}$ and $3 \mu \mathrm{m}$ diameter spherical solid particle tracers in a general circulation model. We investigate factors influencing residence time and distribution of the particles, including emission region, cloud condensation nucleus activity and removal by ice-phase precipitation. The global distribution depends strongly on the assumptions made about uptake into cloud droplets and ice. The transport is also affected, to a lesser extent, by the emission region, particulate diameter, and season. We find that the seasonal variation in atmospheric residence time is insufficient to explain by itself the observed seasonal variation in concentrations of particulate airborne culturable bacteria, indicating that this variability is mainly driven by seasonal variations in culturability and/or emission strength. We examine the potential for exchange of bacteria between ecosystems and obtain rough estimates of the flux from each ecosystem by using a maximum likelihood estimation technique, together with a new compilation of available observations described in a companion paper. Globally, we estimate the total emissions of bacteria-containing particles to the atmosphere to be $7.6 \times 10^{23}-3.5 \times 10^{24} \mathrm{a}^{-1}$, originating mainly from grasslands, shrubs and crops. We estimate the mass of emitted bacteria- to be $40-1800 \mathrm{Gg} \mathrm{a}^{-1}$, depending on the mass fraction of bacterial cells in the particles. In order to improve understanding of this topic, more measurements of the bacterial content of the air and of the rate of surface-atmosphere exchange of bacteria will be necessary. Future observations in wetlands, hot deserts, tundra, remote glacial and coastal regions and over oceans will be of particular interest.
\end{abstract}

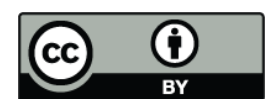

Correspondence to: S. M. Burrows (susannah.burrows@mpic.de)

\section{Introduction}

The transport of microorganisms in the atmosphere could have important implications for several branches of science, including impacts on human health, agriculture, clouds, and microbial biogeography (Burrows et al., 2009). Unraveling these effects has been difficult, partly because so little is known about the concentrations and sources of atmospheric microorganisms, or their transport pathways.

Bacteria are aerosolized from virtually all surfaces, including aerial plant parts, soil and water surfaces (Gregory, 1973; Jones and Harrison, 2004). They can be removed from surfaces by gusts of wind or mechanical disturbances, such as shaking of leaves or surf breaking. Upon entering the air, they can be transported upwards by air currents and, due to their size, remain in the atmosphere for an average period of a few days (Sect. 3). They are eventually removed from the atmosphere by either "dry" deposition - adherence to buildings, plants, the ground and other surfaces in contact with the air - or "wet" deposition - the precipitation of rain, snow or ice that has collected particles while forming or while falling to the surface.

The potential for bacteria and other microorganisms to be transported over long distances through the air has long fascinated microbiologists and been a focus of the field of aerobiology. The average residence time of microorganisms in the atmosphere can range from several days to weeks, long enough for cells to travel between continents. Many microorganisms have defense mechanisms which enable them to withstand the environmental stresses of air transport, including exposure to $\mathrm{UV}$ radiation, dessication, and low $\mathrm{pH}$ within cloud water, so some microorganisms survive this long-range transport to new regions and arrive in a viable state.

Global circulation models and air mass back trajectories have previously been used to investigate the long-range transport of bioaerosols. Andreeva et al. (2002) and Pratt et al. (2009) used back-trajectories to investigate the source region

Published by Copernicus Publications on behalf of the European Geosciences Union. 
of culturable microorganisms and biological ice nuclei, respectively. The long-range transport of fungal spores has been investigated in a model study by Heald and Spracklen (2009), who also used the model to estimate potential global emissions of fungal spores to the atmosphere.

We focus on the transport of bacteria through the air on global scales. Using a general circulation model to simulate particle transport (Sect. 2), we estimate the relative likelihood of transfer of bacteria-sized particulate tracers between various ecosystems. We investigate how particle residence time depends on particle size, emission region and season (Sect. 3).

By adjusting the simulation results to observed concentrations, we estimated the emissions of bacteria from ten lumped ecosystem classes as a first step towards a simple model of emissions of biological particles to the atmosphere (Sect. 4). A realistic estimate of emission rates is an important step towards modeling realistic distributions in various regions. An additional advantage of this approach is that it allows insight into the transfer of genetic material between ecosystems, which has important implications for microbial biogeography. We discuss the estimated distributions and the implications of our results for the co-transport of bacteria and dust, and for ice nucleation (Sect. 5). Further details on the methodology can be found in the appendices, and supplementary tables and figures of simulation results are available in an online supplement: http://www.atmos-chem-phys.net/ 9/9281/2009/acp-9-9281-2009-supplement.pdf.

\section{Model description}

We simulated particle transport using the EMAC model (ECHAM5/MESSy1.5 Atmospheric Chemistry). EMAC is a model system consisting of the atmospheric general circulation model ECHAM5 (Roeckner et al., 2003), coupled to various subprocess models via the Modular Earth Submodel System (MESSy) interface (Jöckel et al., 2005, 2006). The system can be used to simulate both weather and climate, and study their effects on atmospheric chemistry and tracer transport. The model is available to the scientific community upon request (see http://www.messy-interface.org/).

We simulated the transport of aerosol tracers of $1 \mu \mathrm{m}$ and $3 \mu \mathrm{m}$ diameter and $1 \mathrm{~g} \mathrm{~cm}^{-3}$ density (see Sect. 3.3.1 for a discussion of the choice of size). A separate tracer was emitted from each of ten lumped ecosystem classes. Bacteria tracers were initially emitted homogeneously within each region at a rate of $1 \mathrm{~m}^{-2} \mathrm{~s}^{-1}$. This allowed us to determine the fate of bacteria tracers from each ecosystem source region. This rate of emission is arbitrary, and is chosen purely for mathematical convenience. Estimates of the true emission rates were obtained by fitting simulation results to literature estimates of concentrations, (Sect. 4). The bacteria tracers simulate the total concentration of bacterial aerosol found in the air, including both ice-nucleating and non-ice-nucleating species.
The model ran in T63L31 resolution for six simulated years without nudging of wind fields or other data assimilation. Initial meteorological fields were derived from the ECMWF ERA-15 reanalysis for 1 January 1990. Monthly prescribed sea surface temperatures were taken from the AMIP-II data set (available from http://www-pcmdi.llnl. gov/). Initially, no bacteria tracers were present in the air. The global atmospheric burden of the bacteria tracers reached quasi-equilibrium within the first three simulated years (spin-up). ${ }^{1}$ The analysis was conducted using climatological averages of the bacteria tracer distribution during the last three years of the simulation.

The simulations included parameterizations of wet and dry removal processes, as well as transport by advection and parameterized convection. A detailed description of the model set-up is included in Appendix A.

The ecosystem classification was based on the Olson World Ecosystems data set (Olson, 1992). It is illustrated in Fig. 1, and the exact lumping scheme is given in the online supplement: http://www.atmos-chem-phys.net/9/ 9281/2009/acp-9-9281-2009-supplement.pdf. The choice of lumped ecosystem groups necessarily involves compromises. For the lumping used here, taigas were grouped with tundras, since both are boreal, cold and usually frozen regions. However, some other snowy or boreal forests were grouped with forests, a group that also includes forests in tropical, subtropical and moderate climates. Other ambiguous ecosystem types include rice paddies (which could be considered crops or wetlands), mangroves and tidal mudflats (wetlands or coastal), and the various mixed vegetation areas (such as field/woods types). Given the current limited state of knowledge regarding the emissions and distribution of bacteria in the air, it seemed appropriate to limit the number of lumped classes to a small number.

\section{Sensitivity of residence time to source ecosystem, CCN activity, particle size and season}

\subsection{Available laboratory studies on $\mathrm{CCN}$ - and IN-activity of bacteria}

Bauer et al. (2003) found that bacteria in aerosol and cloud water samples were active as cloud condensation nuclei $(\mathrm{CCN})$ at supersaturations between $0.07 \%$ and $0.11 \%$, although insoluble wettable particles of comparable size would not have been activated at such low supersaturations. It therefore seems likely that all or most bacteria are $\mathrm{CCN}$-active in the atmosphere.

\footnotetext{
${ }^{1}$ The long spin-up time allowed the NO-ICE-SCAV simulation, in which the tracers had very long residence times (Table 2), to reach quasi-equilibrium. The same spin-up and was used for the CCN-ACTIVE and CCN-INACTIVE simulations to improve the validity of comparison between the three cases.
} 
Table 1. Removal processes included in the three sensitivity simulations.

\begin{tabular}{lcccccc}
\hline & Sedimentation & Dry deposition & $\begin{array}{c}\text { Impaction and } \\
\text { interception scavenging }\end{array}$ & $\begin{array}{c}\text { Cloud droplet } \\
\text { nucleation }\end{array}$ & $\begin{array}{c}\text { Uptake by } \\
\text { diffusion }\end{array}$ & $\begin{array}{c}\text { Ice-phase scavenging } \\
\text { (impaction and nucleation) }\end{array}$ \\
\hline CCN-ACTIVE & + & + & + & + & + & + \\
CCN-INACTIVE & + & + & + & - & + & + \\
NO-ICE-SCAV & + & + & + & + & + \\
\hline
\end{tabular}

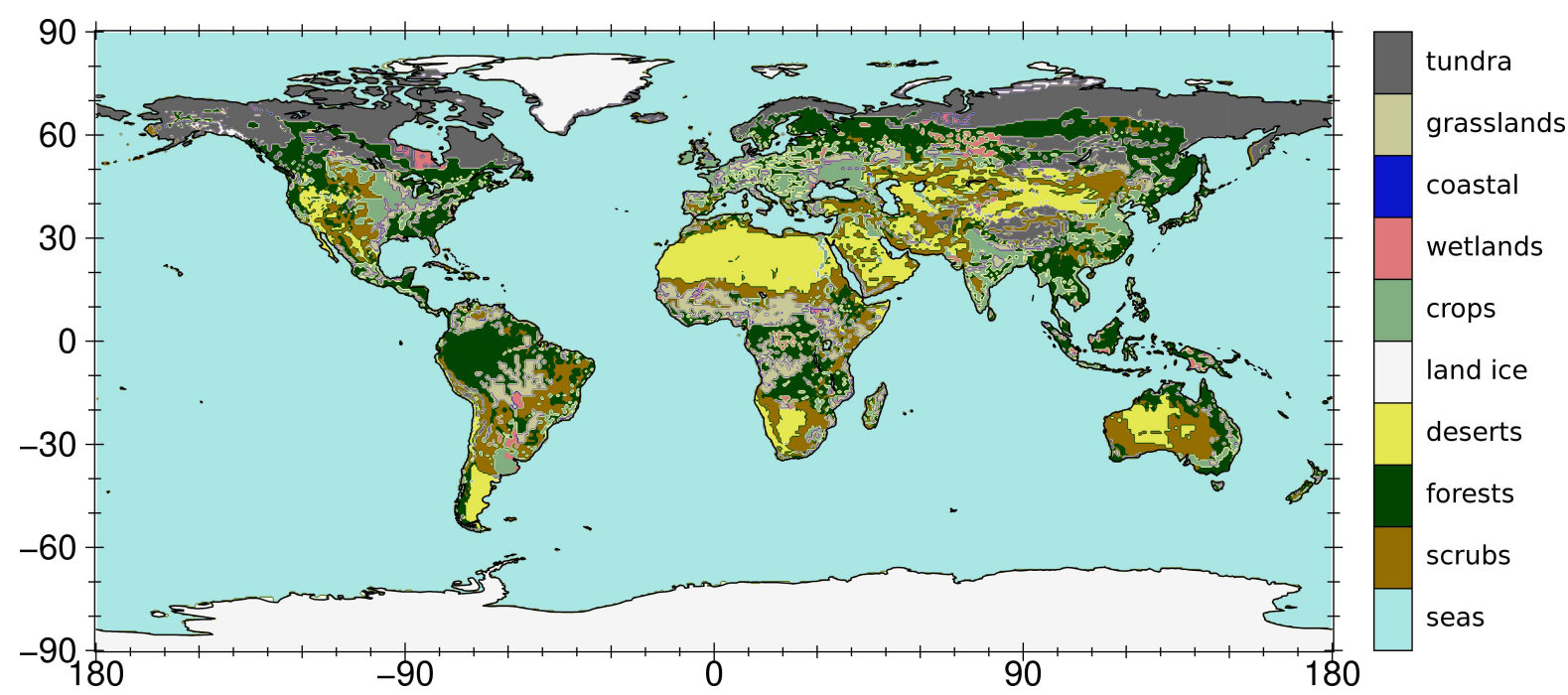

Fig. 1. Lumped ecosystem classes, based on the Olson World Ecosystems (Olson, 1992).

Ice nucleation (IN) activity is limited to very few bacteria (Yankofsky et al., 1981). However, measurements of the scavenged aerosol fraction in mixed-phase clouds have shown that as much as $90 \%$ of the aerosol particles larger than $100 \mathrm{~nm}$ may be found within cloud particles in mixedphase clouds at temperatures above $-6^{\circ} \mathrm{C}$, while at temperatures below $-15^{\circ} \mathrm{C}$ only about $10 \%$ of aerosol particles are found in cloud particles (Henning et al., 2004). By contrast, it has long been clear that only a tiny fraction of aerosol particles (typically less than 1 in 1000) act as ice nuclei (e.g. Mossop, 1963). Observations such as these make clear that non-IN aerosol particles are routinely scavenged by snow and ice, so that for example the observation that a particular particle type is commonly present in snow does not demonstrate that this particle is an active ice nucleator.

For the purposes of this study, we assume that bacteria are scavenged as efficiently by mixed-phase and ice clouds as are aerosol particles in general. The small fraction of bacteria that are IN active may be scavenged at a higher rate, but this should not affect the overall conclusions of this study, which deal with the total concentration of bacteria, rather than the $\mathrm{IN}$-active fraction.

\subsection{Dependence on CNN- and IN-activity}

Model simulations were performed using three different sets of scavenging characteristics to investigate the effects of scavenging processes (removal from the atmosphere by precipitation) on the transport and residence times of bacteria tracers. Losses to dry deposition, and to scavenging by impaction and interception were included in all three simulations, while $\mathrm{CCN}$ activity and ice phase scavenging were varied among the three cases: CCN-ACTIVE, CCN-INACTIVE and NO-ICE-SCAV (Table 1). The scavenging parameterizations used for this study are further discussed in Appendix A3.

The mean global residence times calculated are shown in Table 2. The residence times lie between 2 and 15 days for CCN-ACTIVE and CCN-INACTIVE bacteria tracers, consistent with expectations for particles of this size range (Roedel, 1992). In contrast, the long residence times of over 140 days for bacteria tracers in the NO-ICE-SCAV simulation are unrealistically long. This is interesting in itself, as it demonstrates that ice-phase scavenging, a process crudely represented in many global models, plays a crucial role in determining simulated aerosol concentrations, at least for particles of this size range. For the purposes of this study, it 
Table 2. Global mean atmospheric residence times (days) of bacteria tracers.

\begin{tabular}{|c|c|c|c|c|c|c|c|c|c|c|c|c|}
\hline \multirow[b]{2}{*}{ Simulation } & \multirow[b]{2}{*}{ Diameter } & \multicolumn{11}{|c|}{ Source ecosystem } \\
\hline & & mean & coastal & crops & deserts & forests & grasslands & landice & seas & shrubs & tundra & wetlands \\
\hline \multirow[t]{2}{*}{ CCN-ACTIVE } & $1 \mu \mathrm{m}$ & 3.4 & 4.8 & 5.0 & 9.6 & 3.8 & 4.5 & 7.4 & 2.3 & 6.9 & 5.0 & 4.2 \\
\hline & $3 \mu \mathrm{m}$ & 3.0 & 4.1 & 4.1 & 8.3 & 3.1 & 3.6 & 6.4 & 2.2 & 5.8 & 4.4 & 3.5 \\
\hline \multirow[t]{2}{*}{ CCN-INACTIVE } & $1 \mu \mathrm{m}$ & 7.5 & 9.9 & 9.9 & 14.4 & 8.8 & 10.5 & 9.8 & 6.2 & 11.9 & 8.3 & 9.3 \\
\hline & $3 \mu \mathrm{m}$ & 5.4 & 7.0 & 6.7 & 10.8 & 5.4 & 6.1 & 8.1 & 4.7 & 8.3 & 6.6 & 5.8 \\
\hline NO-ICE-SCAV & $1 \mu \mathrm{m}$ & 158.3 & 168.6 & 171.4 & 188.1 & 165.7 & 174.8 & 113.6 & 155.7 & 179.1 & 144.2 & 167.2 \\
\hline
\end{tabular}

is important to have a realistic representation of residence time, so we will focus only on the results for CCN-ACTIVE and CCN-INACTIVE bacteria tracers in the following discussion. In addition, the following discussion deals only with $1 \mu \mathrm{m}$ CCN-ACTIVE bacteria tracers, but the results for $3 \mu \mathrm{m}$ should not differ by more than about $20 \%$ for CCN-ACTIVE bacteria tracers or $40 \%$ for CCN-INACTIVE tracers, based on the differences in the mean lifetimes (Table 2).

\subsection{Dependence on source region}

The longest global mean residence times are simulated for particles originating in deserts, shrubs and grasslands, together with coastal particles during the boreal summer and tundra and land ice particles during the austral summer. Several of these ecosystems - deserts, shrubs, and grasslands are predominantly located in drier, often tropical climates. Uptake into tropical convective systems and transport to the upper troposphere is likely, and low levels of precipitation in these source regions result in slower removal and thus in longer residence times. Particles emitted in these regions are therefore more likely to participate in long-distance transport. See Sect. 5.3 for further discussion of the co-transport of dust and bacteria.

\subsubsection{Dependence on particulate diameter}

Particles of about $1 \mu \mathrm{m}$ diameter fall into the so-called "scavenging gap" and have atmospheric residence times among the longest for aerosol particles. For particles larger than about $1 \mu \mathrm{m}$, the residence time decreases, resulting in decreased inter-regional transport.

A typical size for a single bacterial cell is about $1 \mu \mathrm{m}-$ E. coli, for instance, is 1.1 to $1.5 \mu \mathrm{m}$ wide by 2.0 to $6.0 \mu \mathrm{m}$ long (Prescott et al., 1996). Atmospheric particles containing bacteria typically have a count median diameter of about 2$4 \mu \mathrm{m}$, these may be single cells or clumps of cells (e.g. Shaffer and Lighthart, 1997; Burrows et al., 2009, and references therein). Recently, the first long-term, continuous online observations were conducted of the size distribution of fluorescent biological aerosol particles at a semi-urban site in Germany (Huffman et al., 2009). Huffman et al. (2009) found a strong, persistent peak in the size distribution occurring at $3 \mu \mathrm{m}$, as well as frequent peaks occurring around $1.5 \mu \mathrm{m}$, $5 \mu \mathrm{m}$, and $13 \mu \mathrm{m}$. The $5 \mu \mathrm{m}$ and $13 \mu \mathrm{m}$ peaks are too large to be bacterial, and can be explained by fungal spores and pollen, respectively. The $1.5 \mu \mathrm{m}$ could be explained by single bacterial cells, and the $3 \mu \mathrm{m}$ could be explained by either fungal spores or agglomerated bacteria.

To test the effect of particle size on transport, we simulated the atmospheric transport of both $1 \mu \mathrm{m}$ and $3 \mu \mathrm{m} \mathrm{CCN}-$ ACTIVE and CCN-INACTIVE particles (Table 2). For the homogeneous CCN-ACTIVE emissions, the mean residence time of $3 \mu \mathrm{m}$ particles is $12 \%$ lower than that of the $1 \mu \mathrm{m}$ particles. The reduction in residence time is smallest for the seas tracer (8\%) and largest for the grasslands tracer $(20 \%)$. For the CCN-INACTIVE tracers, the increase in size results in a greater relative decrease in lifetime.

\subsubsection{Dependence on season}

The strength of emissions of biological particles is likely tied to biological activity and thus dependent on season. This could influence the simulated annual mean concentrations of bacteria in two ways. First, if emissions are correlated (either positively or negatively) with atmospheric residence time for a particular ecosystem, overall mean concentrations would be affected. For example, if both emissions and residence times are highest during summer months, annual mean concentrations would be higher than if the same total emissions were distributed homogeneously in time. Second, if emissions from a particular ecosystem are correlated with seasonal changes in the direction of transport (e.g. the Indian monsoon), the patterns of transport between regions would shift.

To better understand the potential impacts of the seasonality of transport we estimated the change in residence time for each ecosystem tracer relative to its annual emissions. We calculated this separately for each hemisphere so that the signals from opposing hemispheric seasonality do not cancel each other (we assume that inter-hemispheric transport of bacteria tracers is very minor). The relative variations in atmospheric residence time for our bacteria tracers are up to about 20\% (Fig. 2). 
Few field studies investigate the seasonality of atmospheric bacteria, especially of emissions. Those that do typically find higher concentrations of bacteria in the summer than in other seasons, although this is not always the case, and the shorter-term variability of atmospheric bacteria concentrations is at least as large as the differences in concentrations between seasons (Burrows et al., 2009).

Still, the simulated variation in atmospheric residence time can not fully explain the seasonality of concentrations in long-term observations, which show that seasonal mean concentrations of culturable bacteria can vary from at least $20 \%-$ $200 \%$ of the annual mean (Safatov et al., 2006). The remaining seasonal differences are presumably due to a combination of systematic variations in culturability (Tong and Lighthart, 2000) and in emission strength. Probably the seasonal variations in emissions are highest where biological activity dominates emissions and has a strong seasonality. This is supported by the observations of Miquel, who observed culturable bacteria concentrations at four locations in Paris daily from 1888 to 1897. Seasonal differences were smallest near a sewar (seasonal means up to $10 \%$ different from annual mean) and largest in a city park (seasonal means up to $50 \%$ different from annual mean).

In addition to seasonal variability, there may be significant diurnal variability in emissions, which would presumably correlate with atmospheric residence time. The greater turbulence and vertical mixing during the daytime result in a longer residence time for substances emitted during the day than for those emitted at night. This could be a potential aspect for future study.

In the absence of better information about temporal changes in bacterial emissions, we model emissions as constant in time, an assumption which allows straightforward interpretation of the results. Because the seasonal differences in residences times are no more than about $20 \%$, we expect the seasonality of emissions to affect our results (simulated lifetimes, inter-regional exchange, estimated emissions) by no more than about $20 \%$.

\section{Inversion}

This section discusses the estimation of bacterial emissions in each ecosystem class based on a synthesis of literature results (Table 3) and model results. Unless stated otherwise, all results in the remainder of the paper are for $1 \mu \mathrm{m}$ diameter, CCN-ACTIVE bacteria tracers.

\subsection{Observed concentrations}

Our concentration estimates are presented in Table 3 and discussed in detail in a companion paper (Burrows et al., 2009). They are based mainly on the seven field studies listed in the footnotes of Table 3. Some additional assumptions were
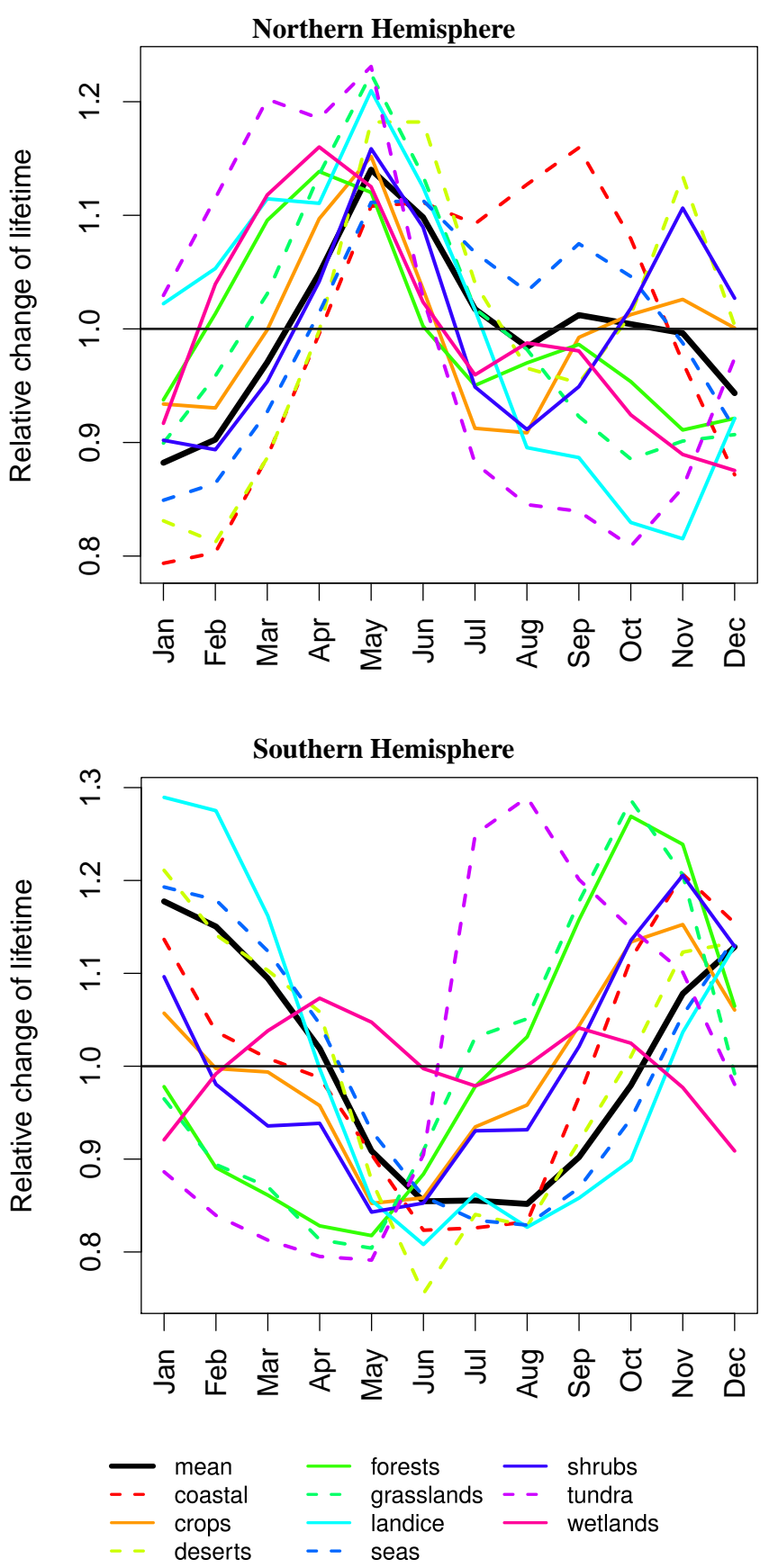

Fig. 2. Relative seasonal variation of residence time: Ratio of monthly mean hemispheric residence time to annual mean hemispheric residence time. "Mean" residence time (thick black line) is calculated for homogeneously emitted bacteria tracer $(1 \mu \mathrm{m}, \mathrm{CCN}$ ACTIVE). 
Table 3. Estimates of total mean bacterial aerosol concentration in near-surface air of various ecosystem types, from Burrows et al. (2009).

\begin{tabular}{lrrrr}
\hline Ecosystem & $\begin{array}{r}\text { Best estimate } \\
\left(\mathrm{m}^{-3}\right)\end{array}$ & $\begin{array}{r}\text { Low estimate }^{\mathrm{b}} \\
\left(\mathrm{m}^{-3}\right)\end{array}$ & $\begin{array}{r}\text { High estimate } \\
\left(\mathrm{m}^{-3}\right)\end{array}$ & $\begin{array}{r}\text { Percent } \\
\text { uncertainty }\end{array}$ \\
\hline coastal $^{\mathrm{d}}$ & $7.6 \times 10^{4}$ & $2.3 \times 10^{4}$ & $1.3 \times 10^{5}$ & 300 \\
crops $^{\mathrm{c}}$ & $1.1 \times 10^{5}$ & $4.1 \times 10^{4}$ & $1.7 \times 10^{5}$ & 81 \\
deserts $^{\mathrm{e}, \mathrm{f}}$ & $\left(1 \times 10^{4}\right)$ & $1.6 \times 10^{2}$ & $3.8 \times 10^{4}$ & 380 \\
forests $^{\mathrm{g}}$ & $5.6 \times 10^{4}$ & $3.3 \times 10^{4}$ & $8.8 \times 10^{4}$ & 100 \\
grasslands $^{\mathrm{c}, \mathrm{h}}$ & $1.1 \times 10^{5}$ & $2.5 \times 10^{4}$ & $8.4 \times 10^{5}$ & 290 \\
land ice $^{\mathrm{i}, \mathrm{j}}$ & $\left(5 \times 10^{3}\right)$ & $\left(1 \times 10^{1}\right)$ & $1 \times 10^{4}$ & 200 \\
seas $^{\mathrm{c}, \mathrm{g}, \mathrm{k}}$ & $1 \times 10^{4}$ & $1 \times 10^{1}$ & $8 \times 10^{4}$ & 800 \\
shrubs $^{\mathrm{f}, \mathrm{g}}$ & $3.5 \times 10^{5}$ & $1.2 \times 10^{4}$ & $8.4 \times 10^{5}$ & 240 \\
tundra $^{\mathrm{e}, \mathrm{g}, \mathrm{l}}$ & $1.2 \times 10^{4}$ & $\left(1 \times 10^{1}\right)$ & $5.6 \times 10^{4}$ & 470 \\
wetlands $^{\mathrm{m}}$ & $9 \times 10^{4}$ & $2 \times 10^{4}$ & $8 \times 10^{5}$ & 870 \\
\hline
\end{tabular}

\footnotetext{
a Additional values have been assumed for fields left blank by Burrows et al. (2009); these are denoted by parentheses and italic font.

$\mathrm{b}$ Percent uncertainties are calculated as best $=($ high - low $) \times 100$.

${ }^{\mathrm{c}}$ Harrison et al. (2005)

${ }^{\mathrm{d}}$ Lighthart and Shaffer (1994)

e Assumed the same best estimate as for seas.

${ }^{\mathrm{f}}$ Shaffer and Lighthart (1997)

$\mathrm{g}$ Tong and Lighthart (1999); Tilley et al. (2001)

$\mathrm{h}$ Bauer et al. (2002)

${ }^{\mathrm{i}}$ Estimated low value for seas taken as lower bound, average of high and low values taken as best estimate.

j Griffin et al. (2006)

${ }^{\mathrm{k}}$ Estimated low value for seas taken as lower bound.

${ }^{1}$ Assumed to be within bounds of best estimates in coastal and grassland/crops regions.
}

made to fill observational gaps; these are also noted in the table.

In the field studies used, values are based on average concentrations of airborne bacteria as observed over a period of a few days to a few weeks. In four of these studies, only the culturable bacteria were observed. Culturable bacteria are typically measured by collecting aerosol samples on a nutrient agar and counting the number of colonies that form during subsequent incubation. In environmental aerosol samples, the culturable bacteria are typically about $1 \%$ of the total aerosol sample, although this fraction also depends on environmental and experimental variables (Burrows et al., 2009). In three studies, total atmospheric bacteria were observed (Tong and Lighthart, 1999; Bauer et al., 2002; Harrison et al., 2005). Total bacteria can be counted by staining proteins in an aerosol sample with a fluorescent dye, and then counting the number of bacteria in a sample under an epifluorescent microscope.

\subsection{Transport matrix}

In the present model, bacteria tracer sources are constant in time and homogeneous within each region. Bacteria tracer sinks (dry and wet deposition) depend linearly on the bacteria tracer concentration. The average bacteria tracer concentration $\bar{x}_{m}$ in the boundary layer of ecosystem $m$ is given by a linear combination of the emission factors $f_{n}$ in the $N$ ecosystems, weighted by a transport matrix $\overline{\mathbf{W}}_{\mathbf{m n}}$ :

$\bar{x}_{m}=\sum_{n=1}^{N} \overline{\mathbf{W}}_{\mathbf{n m}} f_{n}$

The transport matrix $\overline{\mathbf{W}}_{\mathbf{n m}}$ can be calculated directly from the simulated distribution of each ecosystem tracer when emitted homogeneously at $1 \mathrm{~m}^{-2} \mathrm{~s}^{-1}\left(\left(f_{n}=1, n=1, \ldots, N\right)\right)$. The transport matrix $\overline{\mathbf{W}}_{\mathbf{n m}}$ is then given by

$\overline{\mathbf{W}}_{\mathbf{n m}}=\bar{x}_{n m}$,

where $\bar{x}_{n m}$ is the mean concentration of the tracer from ecosystem $n$ in ecosystem $m$. This matrix is similar to the source-receptor matrix often used in transport studies. The source-receptor matrix relates emissions for a set of tracer sources to tracer deposition in a set of "receptor" regions, while our transport matrix $\overline{\mathbf{W}}_{\mathbf{n m}}$ relates a set of tracer sources (the ecosystems) to the tracer concentrations in the lowest model level in a set of regions.

Conceptually, this approach amounts to reducing the output of the global climate model to a ten-box equilibrium model. Mathematically, the approach is equivalent to Green's function synthesis (Enting, 2000). 


\subsection{Calculation of emission estimates}

The free solution of Eq. 1 results in negative surface fluxes for some ecosystems (Fig. 4) and negative simulated total concentrations at some locations (not shown). Therefore, in addition to the free solution, we use a maximum likelihood method to fit the data iteratively while constraining fluxes to be non-negative (details in Appendix B).

Physically, concentrations can not be negative, and mean emission fluxes may be negative only if the model underestimates deposition (because modelled particle sinks are implicitly included in the transport matrix $\overline{\mathbf{W}}_{\mathbf{n m}}$ ). By constraining fluxes to be positive, we essentially assume that the deposition processes included in our simulations are accurate and that the remaining estimated flux includes only the emission.

Although there are also errors in the modelled deposition processes, we believe that the model processes have a higher level of confidence than the highly uncertain literature estimates of bacterial aerosol concentrations. Furthermore, the negative concentrations obtained in the free solution may just be the result of optimizing an unconstrained problem and therefore do not necessarily have a physical explanation.

For this reason, we place greater confidence in the results of the positive-constrained fit than in the free solution. However, because the free solution could potentially provide information about the areas where the deposition flux is underestimated by the model, we also include the free solution for completeness.

\subsection{Simulated transport between ecosystems: transport matrix, external impact of emissions}

We calculated the tranport matrix $\overline{\mathbf{W}}_{\mathbf{n m}}$ for the simulated near-surface concentrations of the CCN-ACTIVE simulation (Table 4). The transport matrix can also be understood as the land-area-weighted impact of ecosystem emissions on concentrations.

We also computed the cross-correlations of the columns of $\overline{\mathbf{W}}_{\mathbf{n m}}$ (Fig. 3). A large positive correlation between two ecosystems in Fig. 3 means that the distribution of the source ecosystem tracer among the ten ecosystem classes is similar, as is likely to occur for geographically adjacent regions. Notable positive correlations occur between seas and coastal regions, which are always contiguous, and between desert and shrub regions, which are almost always contiguous (Fig. 1). All other large positive correlations (correlation $>0.4$ ) involve the forest ecosystem tracer, whose distribution is positively correlated with the distributions of the crops, grasslands, and wetland tracers. Inspection of Fig. 1 shows that these ecosystems are indeed often found adjacent to forested regions.

A large cross-correlation also means that the tracer distributions are significantly linearly dependent on each other. This could point to weaknesses in the ecosystem lumping. For example, for future studies it may be more meaningful
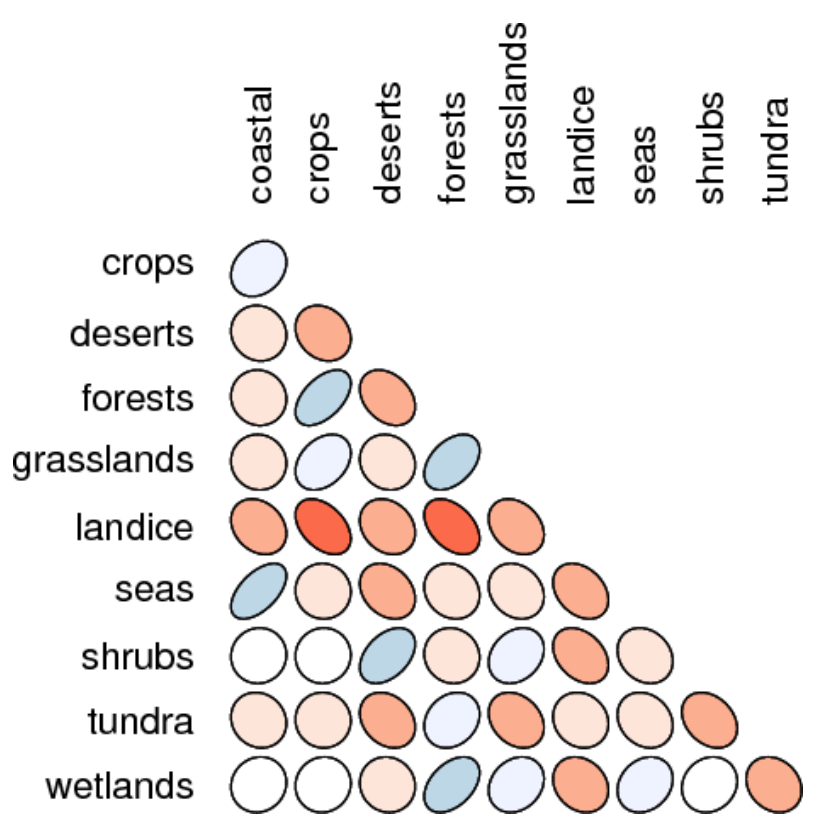

Fig. 3. Cross-correlations of distributions of homogeneously emitted $1 \mu \mathrm{m}$ bacteria tracer from different ecosystems (crosscorrelations of columns in Table 4). Greater elongation of ellipses and higher color saturation indicates higher correlation. Blue, righttilting ellipses represent positive correlations, while red, left-tilting ellipses represent negative values.

to combine the coastal and seas regions, while splitting the forests into several groups that more accurately reflect the diversity of forested ecosystems. A sensible alternate subdivision, however, would ideally also take into account the availability of observations.

\subsection{Emissions estimate}

The positive-constrained fit requires emissions from only six of ten ecosystem classes: coastal, crops, grasslands, shrubs, wetlands, and land ice. Concentrations obtained are within the bounds of literature estimates for each of the ten ecosystem classes (Table 3). With the exception of land ice, these are the ecosystems with the highest estimated bacterial concentrations. Fitted concentrations are lower than literature estimates in four regions (coastal, crop, shrubs, and wetlands), higher in four regions (grasslands, deserts, forests and tundra) and close matches in two regions (land ice and seas). This observation makes clear why in certain regions, the estimated flux is zero in constrained fits and negative in unconstrained fits. The emissions in grassland, crop, and shrub regions are a numerical compromise between the competing goals of fitting high concentrations in those ecosystems and low concentrations elsewhere.

The land ice region is an unusual case. Dominated by the Antarctic continent, it is essentially dynamically decoupled 
Table 4. Transport matrix $\bar{W}_{n m}$ : mean concentrations in near-surface air $\left(\mathrm{m}^{-3}\right)$ of bacteria tracer normalized to an emission rate of $1 \mathrm{~m}^{-2} \mathrm{~s}^{-1}$. Last row is ecosystem area in $10^{6} \mathrm{~km}^{2}$.

\begin{tabular}{|c|c|c|c|c|c|c|c|c|c|c|c|}
\hline & & coastal & crops & deserts & $\begin{array}{l}\text { Sourc } \\
\text { forests }\end{array}$ & $\begin{array}{l}\text { Ecosystem } \\
\text { grasslands }\end{array}$ & landice & seas & shrubs & tundra & wetlands \\
\hline \multirow{12}{*}{$\begin{array}{l}\text { Destination } \\
\text { ecosystem }\end{array}$} & coastal & 15.16 & 33.07 & 26.04 & 28.08 & 20.39 & 1.86 & 167.18 & 33.81 & 4.95 & 3.67 \\
\hline & crops & 2.80 & 76.89 & 21.14 & 55.88 & 34.88 & 0.90 & 70.77 & 26.99 & 5.51 & 2.62 \\
\hline & deserts & 2.07 & 11.91 & 353.15 & 9.15 & 5.24 & 0.33 & 45.52 & 48.22 & 1.16 & 0.92 \\
\hline & forests & 1.73 & 35.32 & 19.29 & 113.00 & 42.92 & 0.69 & 59.41 & 24.73 & 6.84 & 5.40 \\
\hline & grasslands & 1.73 & 29.83 & 48.90 & 52.89 & 131.80 & 0.24 & 47.39 & 49.55 & 1.04 & 3.45 \\
\hline & landice & 0.19 & 0.13 & 0.19 & 0.51 & 0.04 & 593.03 & 30.85 & 0.28 & 1.68 & 0.07 \\
\hline & seas & 1.23 & 6.25 & 8.13 & 7.53 & 3.33 & 11.04 & 189.07 & 8.29 & 2.55 & 0.80 \\
\hline & shrubs & 2.11 & 19.59 & 130.90 & 24.38 & 30.89 & 0.27 & 50.09 & 149.05 & 1.40 & 3.64 \\
\hline & tundra & 1.34 & 19.88 & 1.44 & 57.81 & 3.41 & 5.20 & 48.63 & 7.27 & 63.98 & 0.71 \\
\hline & wetlands & 3.34 & 22.61 & 54.25 & 72.51 & 43.44 & 0.10 & 115.32 & 45.43 & 0.37 & 29.95 \\
\hline & SUM & 31.70 & 255.48 & 663.43 & 421.74 & 316.34 & 613.66 & 824.23 & 393.62 & 89.48 & 51.23 \\
\hline & Ecosystem area & 0.8 & 15.5 & 18.9 & 35.9 & 11.0 & 15.6 & 362.9 & 29.4 & 16.9 & 2.9 \\
\hline
\end{tabular}

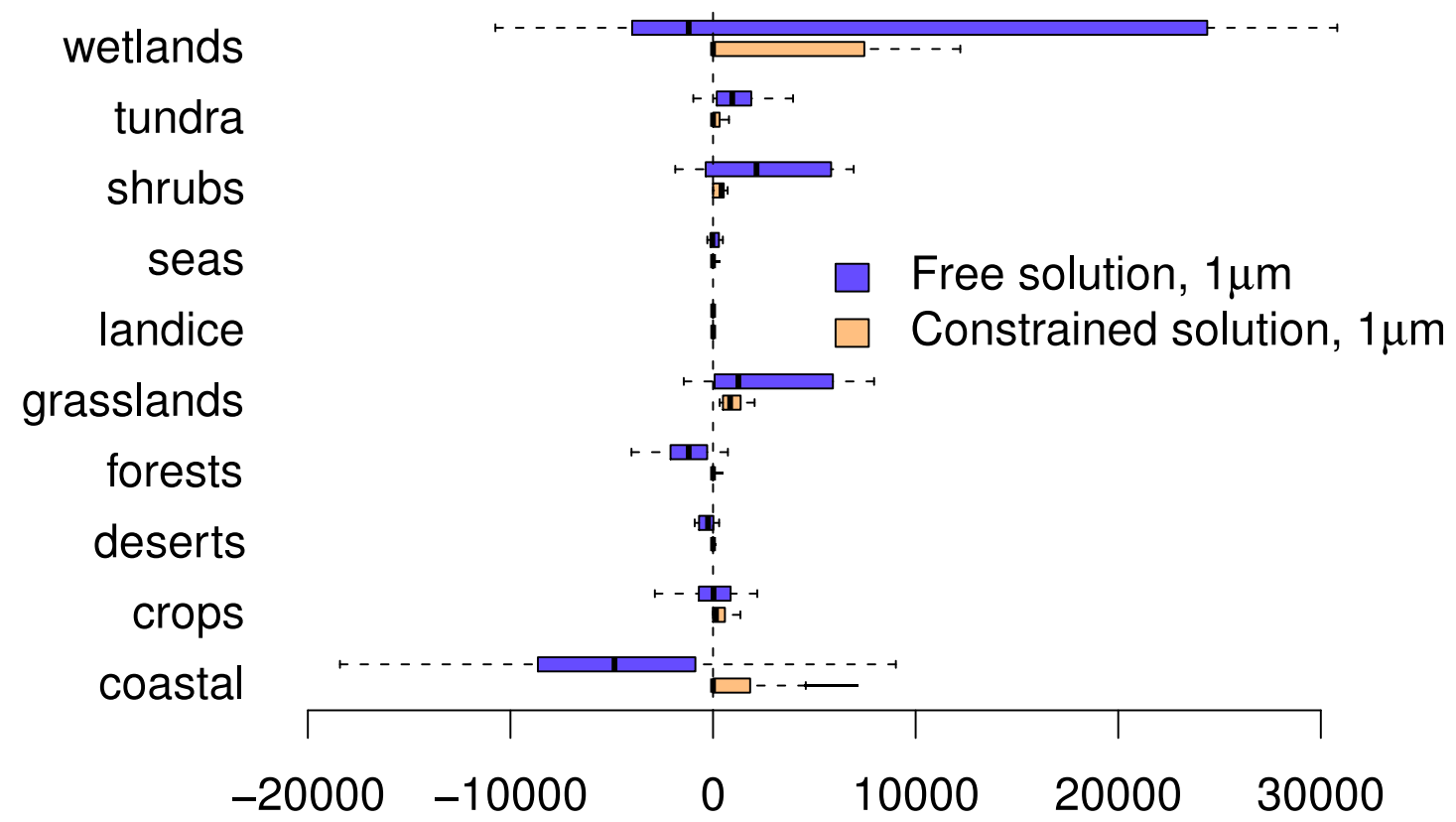

Fig. 4. Box plots of an ensemble of surface-atmosphere flux estimates for bacteria tracers. Fitting was performed for an ensemble of state vectors with elements selected from the low, best and high literature estimates of the mean concentrations in each ecosystem (Table 3 ), resulting in $3^{10}=59049$ ensemble members. Boxes show the $25 \%$-ile to $75 \%$-ile of the estimated fluxes, with marker at median (if the median is not shown, it is zero). Solid lines extend to the extrema.

from the other ecosystem classes. The result is a small exchange of tracers with the seas, and virtually zero tracer exchange with other land ecosystems (Table 4). In addition, particles emitted here have a long residence time (Table 2), so despite low emission estimates, more than $90 \%$ of the aerosol found in the land ice regions is estimated to originate in that region.
In all other regions, contributions from the crop, grassland, and shrub tracers dominate, with these three sources making up about $80-90 \%$ or more of the near-surface load. 


\subsection{Ensemble estimate of uncertainty}

Uncertainties were explored empirically by performing the inversion for an ensemble of vectors with elements taken from the low, middle and high concentration estimates for each region. The distribution of ensemble results is presented for both the free and the constrained solution (Fig. 4; see caption for details of the ensemble simulations).

The model predicts low emissions of bacteria from seas, a result which appears to be robust. The largest uncertainties are found in wetlands and coastal regions, ecosystems with small land areas, which contribute little to the particle content of the air elsewhere. Thus, the emissions in these regions are poorly constrained by concentration estimates elsewhere.

\section{Analysis of adjusted model results}

\subsection{Geographic distribution}

The estimated mean concentration of the total $1 \mu \mathrm{m}$ diameter, CCN-ACTIVE bacteria tracer in the lowest model layer is shown in Fig. 5. The horizontal distribution of the CCNINACTIVE bacteria tracer (not shown) is qualitatively similar, with higher overall concentrations.

In the positive-constrained emissions estimate, there is no emission of bacteria tracer from seas. Still, in some marine regions the simulated concentration can be comparable to concentrations in continental areas without local sources. This continental outflow can be seen more clearly in the distribution of column density (Fig. 6), consistent with a pattern of outflow located primarily higher in the troposphere (not in the boundary layer).

Concentrations are highest in polar regions, consistent with the long residence time of the land ice and tundra tracers (Table 2). High concentrations in sub-Saharan Africa and northwestern Australia coincide with arid regions dominated by grasslands, shrubs and deserts, consistent with long particle residence times (deserts, shrubs) and large relative vertical transport rates (grasslands).

\subsection{Estimated global load and annual emissions}

Overall diagnostics comparing homogeneous emissions to the positive-constrained estimate (adjusted emissions) were calculated (Table 6). The lack of emissions from seas and oceans results in an increased difference between higher concentrations over land and lower concentrations over the seas in the adjusted case. In addition, the global mean tracer residence time is longer for the adjusted emissions case (5.6 days) than for the homogeneous emissions case (3.4 days), with the difference mainly due to the short residence time of bacteria emitted from the ocean.

Taking the median of the ensemble as the best estimate and the 5\%-ile-95\%-ile range as an uncertainty estimate, we estimate that bacteria-containing particles are emitted from land surfaces at an average rate of $250 \mathrm{~m}^{-2} \mathrm{~s}^{-1}$ (range: 140-380), resulting in annual global emissions of bacteria-containing particles of $1.4 \times 10^{24} \mathrm{a}^{-1}\left(7.6 \times 10^{23}-3.5 \times 10^{24}\right)$.

To estimate the emitted mass of bacteria-containing particles, we calculate the total emitted mass of the $1 \mu \mathrm{m}$ bacterial tracer, which is $0.52 \mathrm{pg}$ per particle. We obtain $1400(0$ 4000) $\mathrm{Gga}^{-1}$ of bacteria-containing particles for the free solution and $740(400-1800) \mathrm{Gg} \mathrm{a}^{-1}$ of bacteria-containing particles for the positive-constrained estimate with the constraint that fluxes must be greater than or equal to zero.

However, since airborne bacteria are often attached to larger particles or found as agglomerates (Tong and Lighthart, 2000), the mass of the bacterial cells may be much smaller than the mass of the bacteria-containing particles. Sattler et al. (2001) found that bacteria collected from groundwater had an average volume of $0.052 \mathrm{~m}^{-3}$, which would correspond to a mass of $0.052 \mathrm{pg}$ per cell, one order of magnitude smaller than the mass of our simulated bacterial tracer. Depending on the actual composition of the bacterial particles (mass fraction of bacterial cells), the mass of bacterial cells emitted may range from $40-1800 \mathrm{Gg} \mathrm{a}^{-1}$. This is only a very small fraction of the rough estimate of a total PBAP source of $1000 \mathrm{Tg} \mathrm{a}^{-1}$ (Jaenicke, 2005).

By comparison, Elbert et al. (2007) estimate that global fungal spore emissions amount to a total of about 200 spores $\mathrm{m}^{-2} \mathrm{~s}^{-1}$ over land, comparable to these results. However, with a mean assumed diameter of $5 \mu \mathrm{m}$, a fungal spore has a mass of roughly $65 \mathrm{pg}, 125$ times greater than the approximately $0.52 \mathrm{pg}$ we assume for bacteria-containing particles. For the larger fungal spores, Elbert et al. (2007) assume a mean residence time of 1 day, while bacteria have a mean simulated residence time in our model of between 2 and 10 days, depending on the source ecosystem. Thus, Elbert et al. (2007) estimate a global fungal spore burden of $140 \mathrm{Gg}$ and a source of $50 \mathrm{Tg} \mathrm{a}^{-1}$, much larger than our estimates for bacteria.

\subsection{Relevance for the co-transport with dust and for atmospheric ice nuclei}

The long-distance transport of bacteria together with dust has been discussed in several studies as a mechanism for the global dispersion of microbial species, with the potential to impact ecosystems and public health (Griffin et al., 2001b; Griffin, 2005; Kellogg and Griffin, 2006). Bacteria are known to attach to dust particles and are routinely transported over long distances within dust clouds, where the attenuation of UV radiation by the cloud is believed to improve chances of survival (Griffin et al., 2001a,b). Two recent field studies demonstrated that along with dust, biological particles generally can play an important role as ice nuclei, at least intermittently and at some locations (Prenni et al., 2009; Pratt et al., 2009). 


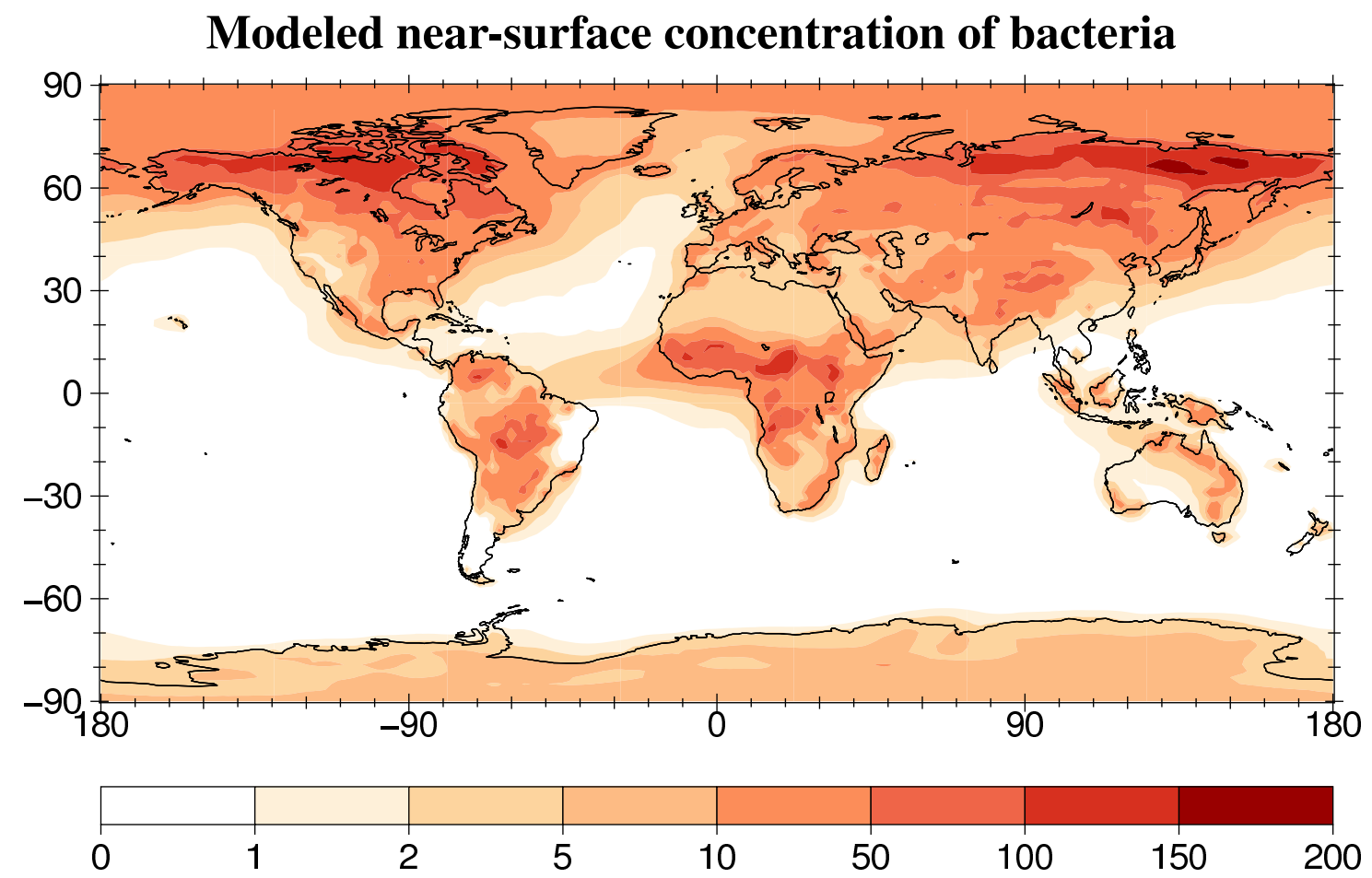

Fig. 5. Modeled concentration of bacteria tracer in near-surface air $\left(10^{3} \mathrm{~m}^{-3}\right)$, with emissions given by the median of the ensemble of positive-constrained emissions estimates.

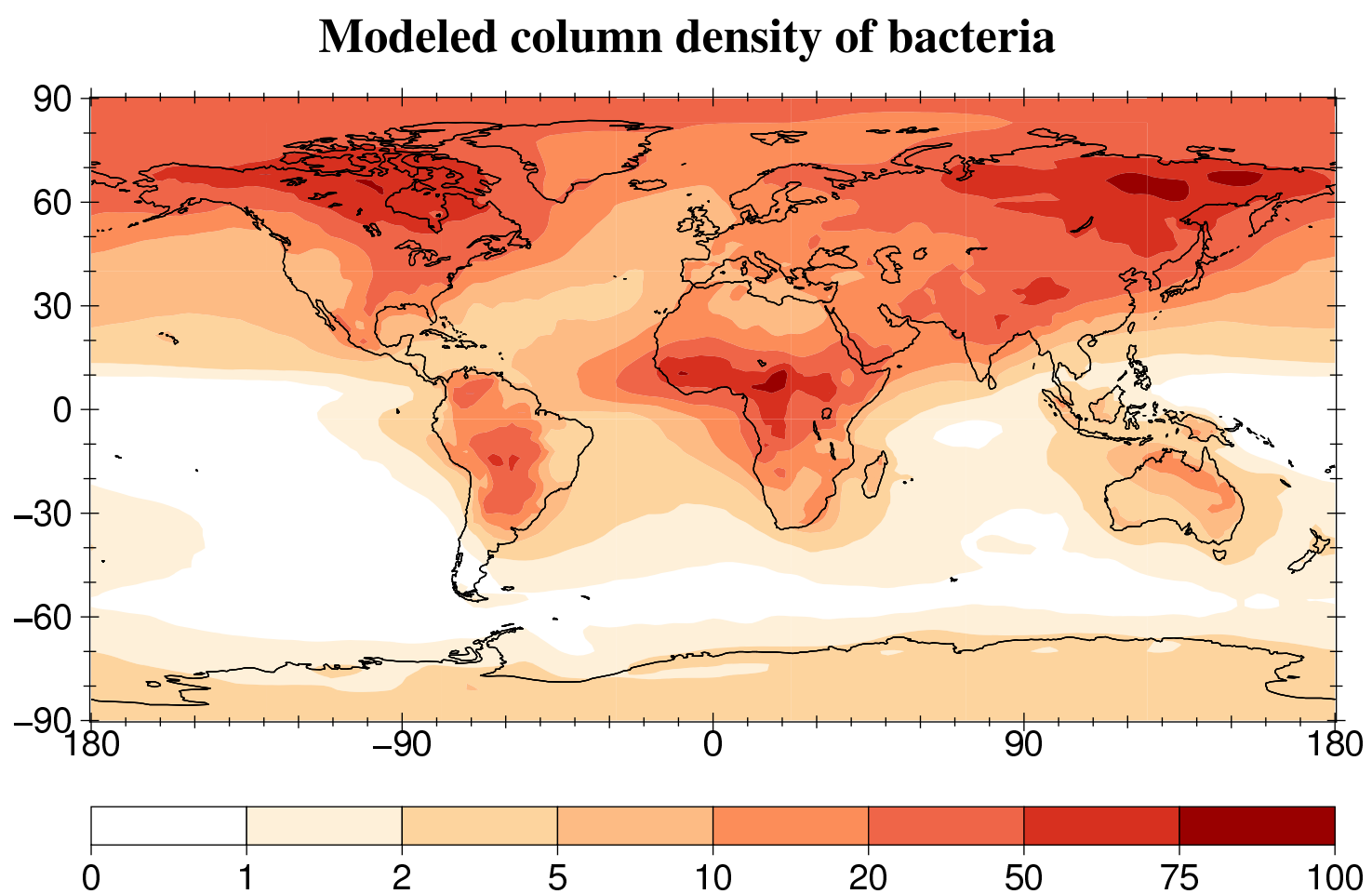

Fig. 6. Column density of bacteria tracer $\left(10^{6} \mathrm{~m}^{-2}\right)$, with emissions given by the median of the ensemble of positive-constrained emissions estimates. 
Table 5. Best-estimate bacteria tracer concentrations: mean concentration of bacteria in near-surface air of destination ecosystem $\left(10^{3} \mathrm{~m}^{-3}\right)$ for positive-constrained emissions estimate.

\begin{tabular}{|c|c|c|c|c|c|c|c|c|c|c|c|c|}
\hline & \multicolumn{12}{|c|}{ Source Ecosystem } \\
\hline & & coastal & crops & deserts & forests & grasslands & landice & seas & shrubs & tundra & wetlands & SUM \\
\hline \multirow{11}{*}{$\begin{array}{l}\text { Destination } \\
\text { ecosystem }\end{array}$} & coastal & 13.6 & 23.3 & 0 & 0 & 13.2 & 0.0143 & 0 & 17.0 & 0 & 0.719 & 67.8 \\
\hline & crops & 2.52 & 54.1 & 0 & 0 & 22.6 & 0.00690 & 0 & 13.5 & 0 & 0.513 & 93.3 \\
\hline & deserts & 1.86 & 8.38 & 0 & 0 & 3.39 & 0.00253 & 0 & 24.2 & 0 & 0.180 & 38.0 \\
\hline & forests & 1.56 & 24.9 & 0 & 0 & 27.8 & 0.00529 & 0 & 12.4 & 0 & 1.06 & 67.7 \\
\hline & grasslands & 1.56 & 21.0 & 0 & 0 & 85.4 & 0.00184 & 0 & 24.9 & 0 & 0.676 & 133 \\
\hline & landice & 0.171 & 0.0915 & 0 & 0 & 0.0259 & 4.54 & 0 & 0.140 & 0 & 0.0137 & 4.99 \\
\hline & seas & 1.11 & 4.40 & 0 & 0 & 2.16 & 0.0846 & 0 & 4.16 & 0 & 0.157 & 12.1 \\
\hline & shrubs & 1.90 & 13.8 & 0 & 0 & 20.0 & 0.00207 & 0 & 74.8 & 0 & 0.713 & 111 \\
\hline & tundra & 1.21 & 14.0 & 0 & 0 & 2.21 & 0.0398 & 0 & 3.65 & 0 & 0.139 & 21.2 \\
\hline & wetlands & 3.01 & 15.9 & 0 & 0 & 28.1 & 0.000766 & 0 & 22.8 & 0 & 5.87 & 75.7 \\
\hline & SUM & 28.5 & 180 & 0 & 0 & 205 & 4.7 & 0 & 197 & 0 & 10.0 & 625 \\
\hline
\end{tabular}

Table 6. Simulated global bacteria with adjusted emission fluxes (positive-constrained estimate) and with homogeneous fluxes normalized to the total global emissions. Global emission estimates given as median (5\% ile - 95\%ile) of ensemble.

\begin{tabular}{|c|c|c|c|}
\hline & & $\begin{array}{l}\text { Estimated } \\
\text { emissions }\end{array}$ & $\begin{array}{l}\text { Homogeneous } \\
\text { emissions }\end{array}$ \\
\hline \multirow{3}{*}{$\begin{array}{l}\text { Mean surface } \\
\text { concentration } \\
\left(10^{3} \mathrm{~m}^{-3}\right)\end{array}$} & Overall & 22 & 23 \\
\hline & Over land & 68 & 33 \\
\hline & Over seas & 12 & 19 \\
\hline \multirow{2}{*}{$\begin{array}{l}\text { Mean emissions } \\
\left(\mathrm{m}^{-2} \mathrm{~s}^{-1}\right)\end{array}$} & From land & $250(140-380)$ & 87 \\
\hline & From seas & $0(0-226)$ & 87 \\
\hline \multicolumn{2}{|c|}{ Mean global load (number) } & $1.7 \times 10^{22}$ & $1.3 \times 10^{22}$ \\
\hline \multicolumn{2}{|c|}{ Mean global load of bacteria-containing particles $(\mathrm{Gg})$} & 8.7 & 6.7 \\
\hline \multicolumn{2}{|c|}{ Mean residence time (days) } & 5.6 & 3.4 \\
\hline \multicolumn{2}{|c|}{ Global emissions $\left(\mathrm{a}^{-1}\right)$} & $1.4 \times 10^{24}\left(7.6 \times 10^{23}-3.5 \times 10^{24}\right)$ & $1.4 \times 10^{24}$ \\
\hline \multicolumn{2}{|c|}{ Global emissions of bacteria-containing particles ${ }^{\mathrm{a}}\left(\mathrm{Gg} \mathrm{a}^{-1}\right)$} & $740(400-1800)$ & 740 \\
\hline
\end{tabular}

a Assuming mass of $0.52 \mathrm{pg}$ per particle, but note that the average mass of an airborne bacterial cell may be as little as $0.052 \mathrm{pg}$ per cell, based on the mean cell volume of $0.052 \mu \mathrm{m}^{3}$ observed by Sattler et al. (2001).

However, it is not yet completely understood how large the relative contributions of local sources and remote sources (particularly deserts) are to the concentration of airborne biological particles in different regions. For bacteria, our results suggest that in general, deserts likely play a less important role as a source of biological matter to the atmosphere than do biologically active regions (Table 5 and Fig. 4). On the other hand, the atmospheric residence time of particles emitted from deserts is much longer than for most other source regions, so particles emitted there are more likely to participate in long-distance transport and be observed in other regions. This is a result of the combination of strong dry convection and a lack of removal by precipitation in desert regions, which have been identified as important factors in studies of dust transport processes in general (e.g. Schulz et al., 1998).

This issue could be better understood through further observations of the concentrations and emission strength in various regions combined with further meteorological analysis of transport from those regions.

\subsection{Limitations and sources of uncertainty}

The approach taken here amounts to the reduction of the global emission and transport of particles to a ten-box system, with sink processes and exchange between the boxes implicitly contained in the transport matrix (Table 4). This approach allows useful insights to be gained into a problem for which the level of knowledge is, at present, very low. 
However, such an approach has limitations, including the following main limitations:

- The ecosystem classification chosen involves various compromises (as discussed in Sect. 1) and some ecosystem classes may not be well-defined for the current purposes. For example, considering the high positive correlation of the coastal and seas tracer distributions (Fig. 3), it might be reasonable to combine these groups. The forest group, on the other hand, includes a variety of diverse regions, and in a future study it might be more meaningful to distinguish between the various types of forest ecosystems.

- Most of the literature estimates (Table 3) are based on a single study or on assumptions about the similarities among ecosystem types. Even in well-studied land types (such as croplands), the variability between sites is high, and the sites studied may not be representative of the entire class.

- We assume the bacteria to have a diameter of $1 \mu \mathrm{m}$; for larger bacteria, inter-region transport would be decreased. We expect the error to be less than about $20 \%$ (Sect. 3.3.1).

- The temporal profile of bacterial emissions is poorly characterized. If temporal variations in emission rates are correlated with residence times in the atmosphere, this correlation would impact the overall mean residence times and the emission estimates; we expect that the results would be affected by less than $20 \%$ (Sect. 3.3.2).

- Emissions of bacteria are likely to depend on temperature, wind, season, time of day, and other meteorological variables (Jones and Harrison, 2004; Burrows et al., 2009), however, little is known about these dependencies at present.

In spite of these limitations, our approach takes advantage of the limited available experimental data to yield first guesses of many values that so far have remained unquantified. This work provides a framework for the interpretation and incorporation of future experimental findings.

\section{Summary and conclusions}

\subsection{Model results: particle transport characteristics}

Using a global chemistry-climate model, we investigated the transport of bacteria in the atmosphere and its sensitivity to scavenging and the source ecosystem. While the ecosystem approach was applied here specifically to study emissions of bacteria, it also provides information about the differences in transport experienced by particles emitted from various ecosystems, and thus may be applicable to other primary biogenic aerosols.

We estimate the mean global atmospheric residence time of a homogeneously emitted bacteria tracer to be about 3.4 days for the CCN-ACTIVE simulation, 7.5 days for CCN-INACTIVE, and several months for NO-ICE-SCAV. These residence times are long enough for significant interecosystem transport to occur in the atmosphere (Table 4). For tracers with the same scavenging characteristics, the residence time varies by up to about a factor of three depending on emission region and season (Table 2). The seasonal variation in residence time is up to about $20 \%$ for $1 \mu \mathrm{m}, \mathrm{CCN}$ ACTIVE tracers, and is insufficient to explain the observed seasonal variations in atmospheric concentrations of culturable bacteria, indicating that seasonal variations in culturability and emission strength must play an important role.

\subsection{Estimation of global emissions of bacterial aerosol}

The results of a literature review (Burrows et al., 2009) and the atmospheric transport simulations were synthesized to obtain a better understanding of the global distribution of bacteria in the atmosphere. Using a maximum likelihood estimation procedure, we estimated emission rates for each of ten ecosystem types. The mean global emissions of bacteria were estimated to be $50-220 \mathrm{~m}^{-2} \mathrm{~s}^{-1}$ (140-380 $\mathrm{m}^{-2} \mathrm{~s}^{-1}$ mean emission rate from land) or 40 $1800 \mathrm{Gg} \mathrm{a}^{-1}$ of bacteria-containing particles, depending on the mass fraction of bacterial cells in the particles. The estimated emissions were mainly from biologically very active regions (grasslands, shrubs, and crops)

The estimated emissions from land are of the same order of magnitude by number as fungal spore emissions, which Elbert et al. (2007) estimated to be about 200 spores $\mathrm{m}^{-2} \mathrm{~s}^{-1}$, while the mass flux is much smaller than the $50 \mathrm{Tg} \mathrm{a}^{-1}$ estimated for total fungal spores due to the smaller size of bacteria.

These emissions result in simulated concentrations consistent with literature measurements showing concentrations to be about $10^{4}-10^{5} \mathrm{~m}^{-3}$ in most regions. This is, based on the broad range of literature reviewed, the first estimate of global bacterial emissions to the atmosphere.

\subsection{Outlook}

Many open questions remain with respect to the role of bacteria in the atmosphere, including:

- How important is "continuous" vs. "intermittent" transport of bacteria? (e.g. Wolfenbarger, 1946)

- How do bacteria influence cloud formation? Does the presence of bacteria affect precipitation or the radiative properties of clouds as part of a larger feedback cycle (the "bioprecipitation" hypothesis)? (Schnell and 
Vali, 1973; Caristi et al., 1991; Sands et al., 1992; Bauer et al., 2003; Morris et al., 2005; Sun and Ariya, 2006)

- To what degree are bacteria able to reproduce in the atmosphere? Does the atmosphere provide a niche for particular microorganisms? (Dimmick et al., 1979; Sattler et al., 2001; Amato et al., 2007)

- Does the degradation of organic compounds by bacteria play a significant role in the chemistry of liquid particles in the atmosphere? (Herlihy et al., 1987; Ariya et al., 2002; Amato et al., 2007)

The answer to each of these questions either depends on or enhances our knowledge of atmospheric bacterial concentrations. Quantifying the distribution of atmospheric bacteria will therefore remain an important goal of investigators seeking to understand interactions between bacteria and the atmospheric environment. Attention should be paid to quantifying total (as opposed to culturable) bacterial concentrations, emission fluxes and vertical profiles. Flux measurements of total bacteria are especially important for improving understanding of the origins of airborne bacteria.

Past measurements of ambient bacterial concentration have tended to focus on urban sites and point sources, or on emissions from agricultural sources. As a result, many ecosystems have been neglected, especially those that are not easily accessible to researchers. Ecosystem types for which no published measurements of airborne bacterial concentrations were found include tropical rain-forests, wetlands, sandy deserts, tundra, and glaciated regions. Also, few measurements have been made over oceans and seas. Measurements of the total concentration, flux and ice-nucleating properties of bacteria over biologically active regions of the oceans would help to clarify whether the marine source makes a significant contribution to the high IN concentrations observed in these regions as argued by Schnell and Vali (1976).

Further laboratory measurements are needed to investigate the activity of bacteria in droplet and ice crystal formation. While it is clear that some bacteria are highly effective ice nucleators, it remains unclear what percentage of environmental bacteria are IN-active or how to treat the $\mathrm{CCN}$ activity of environmental bacteria (CCN activities have been measured by Bauer et al., 2003 and Franc and DeMott, 1998). Studies addressing uptake into cloud and rain droplets would help to quantify the scavenging efficiency for bacteria, and the potential effect of hydrophobic cell surfaces on uptake.

The microbiology of the atmosphere is a topic that presents challenges and opportunities for many disciplines. Atmospheric transport models can make a useful contribution to understanding the sources and distribution of bacteria in the atmosphere. However, there is a need for more measurements, particularly measurements of total (as opposed to viable) bacterial concentrations and fluxes, if further progress is to be made. Because of the many gaps in current knowledge of atmospheric microflora, this study can not be considered complete. Nevertheless, it is expected that the global overview obtained from the current approach, and the estimates of the mean global emissions and concentrations, should be useful in assessing the likely magnitude of effects resulting from the presence of bacteria in the air. Additionally, transport matrices such as the ones we calculate can be used to estimate the inter-ecosystem exchange of other types of biological particles, such as fungal spores (Elbert et al., 2007; Fröhlich-Nowoisky et al., 2009; Huffman et al., 2009).

\section{Appendix A}

\section{Model setup and data handling}

\section{A1 Tracers in EMAC}

In the EMAC system, the back-end for consistent handling of atmospheric constituents is the generic submodel TRACER (Jöckel et al., 2008), which includes two sub-submodels, TRACER_FAMILY and TRACER_PDEF. The sub-submodel TRACER_FAMILY was used to correct small nonlinearities in tracer advection due to operator splitting. The subsubmodel TRACER_PDEF corrects small negative values due to numerical overshoots. The submodel PTRAC was used to define the tracers and their characteristics, including size, density, and CCN activity.

Tracer advection is calculated in EMAC using the Lin and Rood (1996) integration algorithm, which is massconserving, linear, and monotonic in its 1-D form.

The EMAC submodel ONLEM (Kerkweg et al., 2006b,c) enables flexible online calculation of tracer emissions based on a combination of geographical data (e.g. land cover or soil type) and/or current meteorological conditions. ONLEM was extended by a subroutine to simulate the emission of the bacteria tracer.

Sedimentation and other dry deposition processes are simulated by the MESSy submodels SEDI and DRYDEP, respectively (Kerkweg et al., 2006a), while wet deposition is simulated by the MESSy submodel SCAV (Tost et al., 2006).

\section{A2 Dry deposition and sedimentation}

The EMAC parameterization of dry deposition in the submodel DRYDEP is documented in Kerkweg et al. (2006a). Dry deposition is calculated online, considering the effects of Brownian diffusion, impaction and interception onto vegetation, water, bare soil and snow surfaces. Dry deposition on vegetation is calculated using the "big-leaf" approach (Hicks et al., 1987), as parameterized by Slinn (1982) and later modified by Gallagher et al. (2002). Dry deposition on water surfaces is calculated following Slinn and Slinn (1980) over smooth waters and Hummelshøj et al. (1992) over choppy waters. Dry deposition over bare soil and snow surfaces is calculated according to Slinn (1976). 
Dry deposition due to surface interactions only occurs in the lowest model layer, as opposed to sedimentation, which occurs throughout the model and is independent of surface characteristics. For these reasons, sedimentation is treated separately in EMAC, in the SEDI submodel (Kerkweg et al., 2006a). The settling velocity is given by the product of the Stokes settling velocity, multiplied by the Cunningham slip correction (Hinds, 1999).

\section{A3 Wet deposition}

The wet deposition parameterizations used in EMAC are documented in Tost et al. (2006) and Tost (2006). Aerosol scavenging rates were calculated online, in dependence on cloud droplet and raindrop size, rainfall and snowfall intensity and aerosol diameter.

\section{A3.1 Scavenging during cloud droplet nucleation and growth}

The uptake of aerosol particles into cloud droplets due to nucleation on the particles is parameterized by an empirical function for the scavenged fraction, which was derived from measurements presented by Svenningsson et al. (1997) and Martinsson et al. (1999). The nucleation rate for CCN-active particles rises sharply from less than $1 \%$ for $r_{\text {aer }}=0.1 \mu \mathrm{m}$ to $50 \%$ at $r_{\text {aer }}=0.2 \mu \mathrm{m}$ and over $99 \%$ at $r_{\text {aer }}=0.4 \mu \mathrm{m}$. The particles in this study have a radius of $1 \mu \mathrm{m}$, and so are entirely taken up into cloud droplets if assumed to be CCN-active. $\mathrm{CCN}$-inactive particles are not taken up by nucleation scavenging.

\section{A3.2 Scavenging by falling raindrops}

To estimate scavenging by falling raindrops (both within and below the cloud), SCAV uses a semi-empirical parameterization of the collision efficiency $E$ first proposed by Slinn (1983), that includes the effects of Brownian diffusion, interception and impaction scavenging. Its applicability has also been demonstrated by Andronache (2003, 2004).

Removal by impaction and interception scavenging during transport to the upper troposphere is inefficient for the $1 \mu \mathrm{m}$ particles considered in this study. This is because they fall into the so-called "scavenging gap": they are too large for diffusion to be efficient and too small for inertial effects and finite size to be important.

\section{A3.3 Impaction scavenging by frozen hydrometeors}

Although scavenging by falling raindrops is inefficient, impaction scavenging by falling snow and ice is significant, which contributes to the large differences in the simulations with and without ice-phase scavenging. The scavenging coefficient for impaction scavenging by snow and ice is set to 0.1 .

\section{A3.4 Nucleation scavenging by frozen hydrometeors}

The ice content of clouds is represented in EMAC by a single bulk variable. For nucleation scavenging by ice, a constant scavenging ratio is applied (the same approach used in e.g. Stier et al., 2005). For mixed-phase clouds warmer than $238.15 \mathrm{~K}\left(-35^{\circ} \mathrm{C}\right)$, the scavenging coefficient is set to 0.8 ; otherwise it is set to 0.05 . A smaller fraction of the aerosol is scavenged in mixed-phase clouds than in warm clouds. This has been attributed to the Bergeron-Findeisen effect, which leads to growth of a small number of ice crystals at the expense of the evaporation of a larger number of cloud droplets, which release particles (Henning et al., 2004).

Ice phase scavenging was found to be an important removal process, but it is poorly understood at present and its representation in models is crude. For instance, differential scavenging due to the different ice-nucleating capabilities of particles is not considered in the model. Since bacteria are often good ice nucleators, they may be scavenged at higher rates than other aerosol particles, but this effect could not be considered in the current study. Future work is necessary to understand the sensitivity of simulated aerosol distributions to ice-phase scavenging rates and to develop improved scavenging parameterizations.

\section{A3.5 Large scale clouds, deep convection, and vertical diffusion}

In the model set-up used for this study, the vertical transport was parameterized with the submodel CVTRANS. Cumulus convection is calculated via the mass flux scheme of Tiedtke (1989) with modifications for penetrative convection according to Nordeng (1994). Stratiform cloud microphysics is calculated using the parameterization of Lohmann and Roeckner (1996) and the statistical cloud cover scheme of Tompkins (2002). The turbulent vertical flux in the boundary layer is calculated according to Roeckner et al. (2003), Chapter 5.

\section{A4 Data handling}

Model results were output as averages over each six-hour time interval. In post-processing, this output was averaged to obtain "climatological" monthly mean values for mixing ratios and loss rates in each grid cell. The term "climatological" mean is used here to refer to the mean over a particular month of all years, such as the mean over the Januaries of all three simulation years. It is not intended to imply a longterm, truly climatological average.

The analysis was done on the basis of the monthly mean data. Finally, ecosystem emission fluxes were adjusted to fit estimated concentrations from the literature. The numerical procedures used are described in Sect. 4.

The inversion analysis was performed using the opensource statistical programming language $\mathrm{R}$ and its standard libraries (R Development Core Team, 2009). For the 
positive-constrained estimate, the cost function was minimized using a constrained nonlinear optimization function from the $\mathrm{R}$ statistics package (nlminb), which utilizes the routines from the PORT library developed at AT\&T Bell Laboratories (Gay, 1990).

\section{Appendix B Maximum likelihood fitting with positive constraint}

An optimization procedure was applied, in which penalties were placed both on increases in the weighted sum of squared differences, and on modeled mean bacteria concentrations falling outside the range of maximum and minimum estimated values.

The following cost function was minimized:

$$
\begin{aligned}
& \sum_{m=1}^{M} \frac{\left(\bar{x}_{m}-\operatorname{goal}_{m}\right)^{2}}{\left(\operatorname{high}_{m}-\operatorname{low}_{m}\right)}+\mu \cdot\left(\exp \left(\operatorname{low}_{m}-\bar{x}_{m}\right)+\exp \left(\bar{x}_{m}-\operatorname{high}_{m}\right)\right), \\
& \sum_{n=1}^{N} \frac{\left(\bar{x}_{m}-\text { goal }_{m}\right)^{2}}{\left(\operatorname{high}_{m}-\operatorname{low}_{m}\right)}+\mu \cdot\left(\exp \left(\operatorname{low}_{m}-\bar{x}_{m}\right)+\exp \left(\bar{x}_{m}-\operatorname{high}_{m}\right)\right),
\end{aligned}
$$

where $\bar{x}_{m}$ is the average bacteria tracer concentration in the lowest model layer of ecosystem $m$, as in Eq. 1, goal $m$, high $m$ and low $_{m}$ are the best guess, high and low concentration estimates from the literature, respectively, and $\mu$ is a scaling term for the boundary penalty, set to $\mu=0.001$, which is several orders of magnitude smaller than the first term in Eq. B1 for the values we used (given in Table 3). Maximumlikelihood parameters were calculated for the minimum, mean, and maximum literature values, subject to the constraint $f_{n} \geq 0 \mathrm{~m}^{-2} \mathrm{~s}^{-1}$.

Acknowledgements. The authors are grateful to A. Sesartic and two anonymous referees for their many constructive comments, which helped improve the manuscript.

The International Max Planck Research School on Atmospheric Chemistry and Physics is acknowledged gratefully for hosting Susannah Burrows' research, which has been supported under a National Science Foundation Graduate Research Fellowship (grant number 0633824).

The service charges for this open access publication have been covered by the Max Planck Society.

Edited by: R. Cohen

\section{References}

Amato, P., Demeer, F., Melaouhi, A., Fontanella, S., Martin-Biesse, A.-S., Sancelme, M., Laj, P., and Delort, A.-M.: A fate for organic acids, formaldehyde and methanol in cloud water: their biotransformation by micro-organisms, Atmos. Chem. Phys., 7, 4159-4169, 2007,

http://www.atmos-chem-phys.net/7/4159/2007/.

Andreeva, I., Borodulin, A., Buryak, G., et al.: Biogenic Component of Atmospheric Aerosol in the South of West Siberia, Chem. Sust. Dev., 10, 523-537, 2002.

Andronache, C.: Estimated variability of below-cloud aerosol removal by rainfall for observed aerosol size distributions, Atmos. Chem. Phys., 3, 131-143, 2003, http://www.atmos-chem-phys.net/3/131/2003/.

Andronache, C.: Estimates of sulfate aerosol wet scavenging coefficient for locations in the Eastern United States, Atmos. Environ., 38, 795-804, 2004.

Ariya, P., Nepotchatykh, O., Ignatova, O., and Amyot, M.: Microbiological degradation of atmospheric organic compounds, Geophys. Res. Lett., 29, 2077, doi:10.1029/2002GL015637, 2002.

Bauer, H., Kasper-Giebl, A., Löflund, M., Giebl, H., Hitzenberger, R., Zibuschka, F., and Puxbaum, H.: The contribution of bacteria and fungal spores to the organic carbon content of cloud water, precipitation and aerosols, Atmos. Res., 64, 109-119, doi:10.1016/S0169-8095(02)00084-4, 2002.

Bauer, H., Giebl, H., Hitzenberger, R., Kasper-Giebl, A., Reischl, G., Zibuschka, F., and Puxbaum, H.: Airborne bacteria as cloud condensation nuclei, J. Geophys. Res., 108, 4658, doi:10.1029/2003JD003545, 2003.

Burrows, S. M., Elbert, W., Lawrence, M. G., and Pöschl, U.: Bacteria in the global atmosphere: Part 1 - review and synthesis of literature data for different ecosystems, Atmos. Chem. Phys., 9, 9263-9280, 2009,

http://www.atmos-chem-phys.net/9/9263/2009/.

Caristi, J., Sands, D., and Georgakopoulos, D.: Simulation of epiphytic bacterial growth under field conditions, Simulation, 56 295-301, 1991.

Dimmick, R., Wolochow, H., and Chatigny, M.: Evidence for more than one division of bacteria within airborne particles, Appl. Environ. Microb., 38, 642-643, 1979.

Elbert, W., Taylor, P. E., Andreae, M. O., and Pöschl, U.: Contribution of fungi to primary biogenic aerosols in the atmosphere: wet and dry discharged spores, carbohydrates, and inorganic ions, Atmos. Chem. Phys., 7, 4569-4588, 2007, http://www.atmos-chem-phys.net/7/4569/2007/.

Enting, I.: Inverse Methods in Global Biogeochemical Cycles, chap. Green's function methods of tracer inversion, American Geophysical Union, 2000.

Franc, G. and DeMott, P.: Cloud activation characteristics of airborne Erwinia carotovora cells, J. Appl. Meteorol., 37, 12931300, 1998.

Fröhlich-Nowoisky, Pickersgill, D. A., Després, V. R., and Pöschl, U.: High diversity of fungi in air particulate matter, P. Natl. Acad. Sci. USA, 106, 12814 - 12 819, doi:10.1073/pnas.0811003106, 2009.

Gallagher, M., Nemitz, E., Dorsey, J., Fowler, D., Sutton, M., Flynn, M., and Duyzer, J.: Measurements and parameterizations of small aerosol deposition velocities to grassland, arable crops, and forest: Influence of surface roughness length on deposition, 
J. Geophys. Res., 107, 4154, doi:10.1029/2001JD000817, 2002.

Gay, D.: Usage summary for selected optimization routines, Computing Science Technical Report, AT\&T Bell Laboratories, 1990.

Gregory, P.: The microbiology of the atmosphere, Leonard Hill, Aylesbury, UK, 1973.

Griffin, D.: Clouds of desert dust and microbiology: a mechanism of global dispersion, Microbiol. Today, 32, 180-182, 2005.

Griffin, D., Garrison, V., Herman, J., and Shinn, E.: African desert dust in the Caribbean atmosphere: Microbiology and public health, Aerobiologia, 17, 203-213, 2001a.

Griffin, D., Kellogg, C., and Shinn, E.: Dust in the wind: Long range transport of dust in the atmosphere and its implications for global public and ecosystem health, Global Change and Human Health, 2, 20-33, 2001b.

Griffin, D., Westphal, D., and Gray, M.: Airborne microorganisms in the African desert dust corridor over the mid-Atlantic ridge, Ocean Drilling Program, Leg 209, Aerobiologia, 22, 211-226, 2006.

Harrison, R., Jones, A., Biggins, P., Pomeroy, N., Cox, C., Kidd, S., Hobman, J., Brown, N., and Beswick, A.: Climate factors influencing bacterial count in background air samples, Int. J. Biometeorol., 49, 167-178, 2005.

Heald, C. L. and Spracklen, D. V.: Atmospheric budget of primary biological aerosol particles from fungal spores, Geophys. Res. Lett., 36, L09806, doi:10.1029/2009GL037493, 2009.

Henning, S., Bojinski, S., Diehl, K., Ghan, S., Nyeki, S., Weingartner, E., Wurzler, S., and Baltensperger, U.: Aerosol partitioning in natural mixed-phase clouds, Geophys. Res. Lett., 31, L06 101, doi:10.1029/2003GL019025, 2004.

Herlihy, L., Galloway, J., and Mills, A.: Bacterial utilization of formic and acetic acid in rainwater, Atmos. Environ., 21, 23972402, 1987.

Hicks, B., Baldocchi, D., Meyers, T., Hosker, R., and Matt, D.: A preliminary multiple resistance routine for deriving dry deposition velocities from measured quantities, Water Air Soil Poll., 36, 311-330, 1987.

Hinds, W. C.: Aerosol technology: properties, behavior, and measurement of airborne particles, Wiley-Interscience, second edn., 483 pp., 1999.

Huffman, J. A., Treutlein, B., and Pöschl, U.: Fluorescent biological aerosol particle concentrations and size distributions measured with an ultraviolet aerodynamic particle sizer (UV-APS) in Central Europe, Atmos. Chem. Phys. Discuss., 9, 17705-17751, 2009,

http://www.atmos-chem-phys-discuss.net/9/17705/2009/.

Hummelshøj, P., Jensen, N., and Larson, S.: Precipitation scavenging and atmosphere-surface exchange, chap. Particle dry deposition to a sea surface, Hemisphere Publishing Corporation, Washington, 1992.

Jaenicke, R.: Abundance of cellular material and proteins in the atmosphere, Science, 308, 73, doi:10.1126/science.1106335, 2005.

Jöckel, P.: Technical note: Recursive rediscretisation of geoscientific data in the Modular Earth Submodel System (MESSy), Atmos. Chem. Phys., 6, 3557-3562, 2006, http://www.atmos-chem-phys.net/6/3557/2006/.

Jöckel, P., Sander, R., Kerkweg, A., Tost, H., and Lelieveld, J.: Technical Note: The Modular Earth Submodel System (MESSy) - a new approach towards Earth System Modeling, Atmos. Chem.
Phys., 5, 433-444, 2005,

http://www.atmos-chem-phys.net/5/433/2005/.

Jöckel, P., Tost, H., Pozzer, A., Brühl, C., Buchholz, J., Ganzeveld, L., Hoor, P., Kerkweg, A., Lawrence, M. G., Sander, R., Steil, B., Stiller, G., Tanarhte, M., Taraborrelli, D., van Aardenne, J., and Lelieveld, J.: The atmospheric chemistry general circulation model ECHAM5/MESSy1: consistent simulation of ozone from the surface to the mesosphere, Atmos. Chem. Phys., 6, 5067-5104, 2006.

Jöckel, P., Kerkweg, A., Buchholz-Dietsch, J., Tost, H., Sander, R., and Pozzer, A.: Technical Note: Coupling of chemical processes with the Modular Earth Submodel System (MESSy) submodel TRACER, Atmos. Chem. Phys., 8, 1677-1687, 2008, http://www.atmos-chem-phys.net/8/1677/2008/.

Jones, A. M. and Harrison, R. M.: The effects of meteorological factors on atmospheric bioaerosol concentrations - a review, Sci. Total Environ., 326, 151-180, 2004.

Kellogg, C. and Griffin, D.: Aerobiology and the global transport of desert dust, Trends Ecol. Evol., 21, 638-644, 2006.

Kerkweg, A., Buchholz, J., Ganzeveld, L., Pozzer, A., Tost, H., and Jöckel, P.: Technical Note: An implementation of the dry removal processes DRY DEPosition and SEDImentation in the Modular Earth Submodel System (MESSy), Atmos. Chem. Phys., 6, 4617-4632, 2006,

http://www.atmos-chem-phys.net/6/4617/2006/.

Kerkweg, A., Sander, R., Tost, H., and Jöckel, P.: MESSy Emissions Users Manual, Air Chemistry Department, Max-Planck Institute of Chemistry, P.O. Box 3060, 55020 Mainz, Germany, akerkweg@mpch-mainz.mpg.de, 2006b.

Kerkweg, A., Sander, R., Tost, H., and Jöckel, P.: Technical note: Implementation of prescribed (OFFLEM), calculated (ONLEM), and pseudo-emissions (TNUDGE) of chemical species in the Modular Earth Submodel System (MESSy), Atmos. Chem. Phys., 6, 3603-3609, 2006,

http://www.atmos-chem-phys.net/6/3603/2006/.

Lighthart, B. and Shaffer, B. T.: Bacterial flux from chaparral into the atmosphere in mid-summer at a high desert location, Atmos. Environ., 28, 1267-1274, 1994.

Lin, S. and Rood, R.: Multidimensional Flux-Form SemiLagrangian Transport Schemes, Mon. Weather Rev., 124, 20462070, 1996.

Lohmann, U. and Roeckner, E.: Design and performance of a new cloud microphysics scheme developed for the ECHAM general circulation model, Clim. Dynam., 12, 557-572, 1996.

Martinsson, B., Frank, G., Cederfelt, S., Swietlicki, E., Berg, O., Zhou, J., Bower, K., Bradbury, C., Birmili, W., Stratmann, F., et al.: Droplet nucleation and growth in orographic clouds in relation to the aerosol population, Atmos. Res., 50, 289-315, 1999.

Morris, C., Georgakopoulos, D., and Sands, D.: Ice nucleation active bacteria and their potential role in precipitation, J. Phys. IV France, 121, 87-103, 2005.

Mossop, S.: Atmospheric ice nuclei, Z. Angew. Math. Phys. (ZAMP), 14, 456-486, 1963.

Nordeng, T. E.: Extended versions of the convective parameterization scheme at ECMWF and their impact on the mean and transient activity of the model in the tropics., ECMWF, Reading, UK, Tech. Rep., Technical Memorandum 206, 1994.

Olson, J.: World ecosystems (WE1.4): Digital raster data on a 10 minute geographic 1080 (2160 grid square), Global 
Ecosystem Database, Version, 1, 1992.

Pratt, K., DeMott, P., French, J., Wang, Z., Westphal, D., Heymsfield, A., Twohy, C., Prenni, A., and Prather, K.: In situ detection of biological particles in cloud ice-crystals, Nat. Geosci., 2, 398401, 2009.

Prenni, A., Petters, M., Kreidenweis, S., Heald, C., Martin, S., Artaxo, P., Garland, R., Wollny, A., and Pöschl, U.: Relative roles of biogenic emissions and Saharan dust as ice nuclei in the Amazon basin, Nat. Geosci., 2, 402-405, doi:10.1038/NGEO517, 2009.

Prescott, L., Harley, J., and Klein, D.: Microbiology, Wm. C. Brown Publishers, Dubuque, IA, third edition, 37-41 pp., 1996.

R Development Core Team: R: A Language and Environment for Statistical Computing, R Foundation for Statistical Computing, Vienna, Austria, http://www.r-project.org, last access: 30 November 2009, ISBN 3-900051-07-0, 2009.

Roeckner, E., Bauml, G., Bonaventura, L., Brokopf, R., Esch, M., Giorgetta, M., Hagemann, S., Kirchner, I., Kornblue, L., Manzini, E., et al.: The atmospheric general circulation model ECHAM5, Part 1: Model description, Max Planck Institute for Meteorology, Hamburg, Tech. Rep. 349, 2003.

Roedel, W.: Physik unserer Umwelt, Die Atmosphäre, Berlin Heidelberg, 1992.

Safatov, A., Andreeva, I., Buryak, J., et al.: The results of 7-year monitoring of the biogenic components of atmospheric aerosol in Southwestern Siberia, Chem. Eng. T., 10, 401, 2006.

Sands, D., Langhans, V., Scharen, A., and DeSmet, G.: The association between bacteria and rain and possible resultant meteorological implications, Idojaras (Budapest), 86, 148-152, 1992.

Sattler, B., Puxbaum, H., and Psenner, R.: Bacterial growth in supercooled cloud droplets, Geophys. Res. Lett., 28, 239-242, doi:10.1029/2000GL011684, 2001.

Schnell, R. and Vali, G.: World-wide source of leaf-derived freezing nuclei, Nature, 246, 212-213, 1973.

Schnell, R. and Vali, G.: Biogenic Ice Nuclei: Part I, Terrestrial and Marine Sources, J. Atmos. Sci., 33, 1554-1564, 1976.

Schulz, M., Balkanski, Y. J., Guelle, W., and Dulac, F.: Role of aerosol size distribution and source location in a threedimensional simulation of a Saharan dust episode tested against satellite-derived optical thickness, J. Geophys. Res., 103, 1057910592, doi:10.1029/97JD02779, 1998.

Shaffer, B. T. and Lighthart, B.: Survey of Culturable Airborne Bacteria at Four Diverse Locations in Oregon: Urban, Rural, Forest, and Coastal, Microb. Ecol., 34, 167-177, 1997.

Slinn, S. A. and Slinn, W. G. N.: Predictions for particle deposition on natural waters, Atmos. Environ., 14, 1013-1016, doi:10.1016/0004-6981(80)90032-3, 1980.

Slinn, W.: Precipitation scavenging, dry deposition and resuspension, chap. 11, Precipitation Scavenging, United States Dept. of Energy, 1983.

Slinn, W. G. N.: Atmosphere-surface exchange of particulate and gaseous pollutants, chap. Dry deposition and resuspension of aerosol particles - a new look at some old problems, US DOE Tech. Info. Center, Oak Ridge, TN, USA, 1976.
Slinn, W. G. N.: Predictions for particle deposition to vegetative canopies, Atmos. Environ., 16, 1785-1794, doi:10.1016/00046981(82)90271-2, 1982.

Stier, P., Feichter, J., Kinne, S., Kloster, S., Vignati, E., Wilson, J., Ganzeveld, L., Tegen, I., Werner, M., Balkanski, Y., Schulz, M., Boucher, O., Minikin, A., and Petzold, A.: The aerosolclimate model ECHAM5-HAM, Atmos. Chem. Phys., 5, 1125 1156, 2005, http://www.atmos-chem-phys.net/5/1125/2005/.

Sun, J. and Ariya, P. A.: Atmospheric organic and bio-aerosols as cloud condensation nuclei $(\mathrm{CCN})$ : A review, Atmos. Environ., 40, 795-820, doi:10.1016/j.atmosenv.2005.05.052, 2006.

Svenningsson, B., Hansson, H., Martinsson, B., Wiedensohler, A., Swietlicki, E., Cederfelt, S., Wendisch, M., Bower, K., Choularton, T., and Colvile, R.: Cloud droplet nucleation scavenging in relation to the size and hygroscopic behaviour of aerosol particles, Atmos. Environ., 31, 2463-2475, 1997.

Tiedtke, M.: A comprehensive mass flux scheme for cumulus parameterization in large-scale models, Mon. Weather Rev., 117, 1779-1800, doi:10.1175/15200493(1989)117;1779:ACMFSF $; 2.0 . C O ; 2,1989$.

Tilley, R., Eamus, D., and Ho, J.: Background Bioaerosols and Aerosols at Two Sites in Northern Australia: Preliminary Measurements, Tech. rep., DSTO Aeronautical and Maritime Research Laboratory, Victoria, Australia, 2001.

Tompkins, A.: A prognostic parameterization for the subgrid-scale variability of water vapor and clouds in large-scale models and its use to diagnose cloud cover, J. Atmos. Sci., 59, 1917-1942, 2002.

Tong, Y. and Lighthart, B.: Diurnal Distribution of Total and Culturable Atmospheric Bacteria at a Rural Site, Aerosol Sci. Tech., 30, 246-254, 1999.

Tong, Y. and Lighthart, B.: The annual bacterial particle concentration and size distribution in the ambient atmosphere in a rural area of the Willamette Valley, Oregon, Aerosol Sci. Tech., 32, 393-403, doi:10.1080/027868200303533, 2000.

Tost, H.: Global Modelling of Cloud, Convection and Precipitation Influences on Trace Gases and Aerosols, Ph.D. thesis, Rheinische Friedrich-Wilhelms-Universitat Bonn, Germany, available online at: http://hss.ulb.uni-bonn.de/diss_online, last access: 30 November 2009, 2006.

Tost, H., Jöckel, P., Kerkweg, A., Sander, R., and Lelieveld, J.: Technical note: A new comprehensive SCAVenging submodel for global atmospheric chemistry modelling, Atmos. Chem. Phys., 6, 565-574, 2006, http://www.atmos-chem-phys.net/6/565/2006/.

Wolfenbarger, D. O.: Dispersion of Small Organisms, Distance Dispersion Rates of Bacteria, Spores, Seeds, Pollen, and Insects; Incidence Rates of Diseases and Injuries, Am. Midl. Nat., 35, 1-152, 1946 .

Yankofsky, S. A., Levin, Z., Bertold, T., and Sandlerman, N.: Some basic characteristics of bacterial freezing nuclei, J. Appl. Meteorol., 20, 1013-1019, 1981. 